\title{
The Influences of Service Quality and Individual Characteristics on Vocational Training Effectiveness
}

\author{
Wei Hsu * iD and Pei-Wen Chen
}

check for

updates

Citation: Hsu, W.; Chen, P.-W. The Influences of Service Quality and Individual Characteristics on Vocational Training Effectiveness. Sustainability 2021, 13, 13207. https:/ / doi.org/10.3390/su132313207

Academic Editor: Caterina Gozzoli

Received: 13 October 2021

Accepted: 24 November 2021

Published: 29 November 2021

Publisher's Note: MDPI stays neutral with regard to jurisdictional claims in published maps and institutional affiliations.

Copyright: (c) 2021 by the authors. Licensee MDPI, Basel, Switzerland. This article is an open access article distributed under the terms and conditions of the Creative Commons Attribution (CC BY) license (https:// creativecommons.org/licenses/by/ $4.0 /)$.
Department of Health Care Management, National Taipei University of Nursing and Health Sciences, Beitou, Taipei 112303, Taiwan; nikki545555@gmail.com

* Correspondence: weihsu@ntunhs.edu.tw

\begin{abstract}
With the rapid change of the industrial environment and social development, vocational training must be constantly updated in accordance with these changes, and combine and expand the use of civilian training resources to increase vocational training pipelines and enhance competitiveness. Thus, vocational training organizations play an important role in the function of future labor force development and the sustainability of education. The purpose of this study is to explore the influences of training organizations' service quality and trainees' individual characteristics on the effectiveness of the vocational training. The study employed Kirkpatrick's evaluation model to measure the unemployed effectiveness of the vocational training and the SERVQUAL to quantity the service quality of the vocational training organization. A questionnaire survey was conducted at a vocational training organization for beauty and hairdressing in Taiwan. This study distributed 479 questionnaires and obtained 216 valid samples. The data was analyzed by using the reliability analysis, descriptive analysis, analysis of variance, and multiple linear regression analysis. The results revealed that training organizations' service quality and trainees' personal characteristics significantly positively affect training effectiveness for trainees. This paper serves as a reference for training organizations and policy makers to improve and monitor the service quality of vocational training organizations, elevate training effectiveness, and achieve the sustainability of vocational educations.
\end{abstract}

Keywords: Kirkpatrick's evaluation model; service quality; self-efficacy; learning motivation; vocational training

\section{Introduction}

Vocational education was one of the key factors driving Taiwan's rapid economic growth in the past decades [1]. This form of adult education continuously boosts the future economy and human capital [2]. Vocational training for unemployed laborers is an important measure taken by Taiwan's Workforce Development Agency of the Ministry of Labor in an attempt to address the unemployment issue. It plans and organizes various employment-oriented training for unemployed, employment-pending, or resettling laborers who lack professional skills or need additional skills, for the purposes of improving laborers' practical job skills, facilitating their employment and livelihood. Since the self-organized training by the Center for Vocational Training has limited categories and quantity, the majority of the training sessions are carried out using a "diversified training model" and are commissioned by private organizations either directly or through subsidizing local governments. The proportions of such sessions are increasingly growing. Because various training programs target people's different needs, the number of people who were trained by the commissioned training organizations is larger than the number of people trained at the self-organized training by the Workforce Development Agency in recent years.

For the purpose of evaluating training effectiveness, the Workforce Development Agency includes the "administration", "implementation of training", and "performance of 
training" as the main content for assessment to give scores for the next year's evaluation. It is fair to say that service quality and training effectiveness are important criteria for assessing commissioned training organizations. Moreover, more private organizations are commissioned year by year. As a long-term goal, government bodies and training organizations should attempt to continuously ensure quality vocational training for trainees, as well as enable trainees to choose government-backed vocational training organizations when they need training again.

For unemployed trainees, the primary outcome they expect from the training is to get employed. There are many factors influencing training effectiveness, and past literature suggests that the ability and motivation of trainees, when combined, can determine training effectiveness [3-5]. That is to say, when trainees are motivated and able to learn, the performance of the training will be enhanced. Personal characteristics, such as self-efficacy and learning motivation, are important factors influencing training effectiveness [3,6-9]. The literature review shows that many studies in the past discussed the service quality of vocational training organizations [10,11]. However, previous literature has not investigated the relationships among service quality, the personal characteristics of trainees, and training effectiveness of training organizations. Thus, the purpose of this study is to examine how service quality variables of commissioned training organizations and trainees' personal characteristic variables make differences in the effectiveness of training, as well as the predictive power of service quality variables of commissioned training organizations and trainees' personal characteristics variables toward training effectiveness.

Among the self-organized vocational training sessions conducted by public training organizations of Taiwan's Workforce Development Agency, numerous people completing the training for service industries, such as beauty and hairdressing services, account for the largest proportion of trainees from the entire occupation and make up a quarter of the total number of trainees for the entire year. Currently, there is no study about the efficacy of training sessions targeting beauty and hairdressing occupations, which account for the largest proportion of participating and graduated trainees, nor is there a study about the relationship between service quality, the personal characteristics of trainees, and training effectiveness. Therefore, this study analyzes factors related to training effectiveness with a specific focus on vocational training in beauty and hairdressing occupations.

There are two main aspects of research contributions in this study. From an academic standpoint, the research results of this study could make up the shortage of relevant studies on vocational training for unemployed beauty and hairdressing laborers; from a practical standpoint, the results could contribute to training organizations and the Workforce Development Agency, who can have a reference for reviewing their status quo and room for improvement, enabling vocational training to have a better impact, and boosting the maximum benefit from training to achieve sustainable vocational trainings.

\section{Literature Review}

\subsection{Vocational Training Effectiveness}

Training is a planned learning experience that can permanently change an individual's knowledge, attitude, and skills [12]. The trainings for employees and employers are important and valuable, given that with newly acquired knowledge and skills, employees can better perform their duties or even carry out tasks that are more creative and complex. Therefore, training provides better career development opportunities for employees as well as making them more competitive [13]. With regards to training effectiveness, Bushnell [14] believed that training effectiveness is composed of the training's output in the short term as well as the training's outcome in the long run. Training effectiveness measures the studying outcome of trainees and their performance at work afterwards [15]. Training effectiveness evaluation is generally defined as a systematic process that collects a training's outcome for the purpose of determining whether the training is effective [16], while also being conducive to improving the quality of training [17]. Kirkpatrick [18] divided training 
effectiveness evaluation into four levels: the reaction level, learning level, behavior level, and result level. The contents of the four levels are described below.

First, the reaction level mainly measures how the trainees react to the training programs, including their degree of satisfaction with the faculty, program content, training materials, pedagogics, air-conditioning equipment, and so forth. This level focuses on measuring the degree of the trainees' satisfaction and feelings, rather than any knowledge or acquired skills. Kirkpatrick and Kirkpatrick [19] put forth that the result at a higher level can only be measured when the result at a lower level changes; if trainees are not satisfied with the training, they would be reluctant to study, much less to improve to the next level.

Second, the learning level mainly measures whether trainees gain relevant knowledge and skills through training, i.e., whether trainees learn something that they did not know prior to the training, as well as how much they understand and digest such content. Kirkpatrick and Kirkpatrick [19] believed that if the learning objective is not met, there is no chance of behavioral change. Some studies also point out that personal characteristics, such as ability, personality, and motivation, influence factors for the next stage of training to get transferred $[20,21]$.

Third, the behavior level mainly measures the extent of the application of knowledge and skills acquired through training in practical work by trainees. That is, the behavior level judges the extent of learning that is transferred to and influences practical work. Kirkpatrick [18] pointed out that since there are positive correlations among these levels, it is not permitted to skip the levels of reaction and learning and go straight to behavioral evaluation.

Finally, the result level mainly measures the effect of training on the organization's performance and the trainees. In other words, how do trainees make positive contributions to the business performance of the organization through participating in training? Kirkpatrick and Kirkpatrick [19] explained that evaluating the result level is the most difficult because the trainees do not understand the evaluation mechanism, the time span between the end of training and the demonstration of performance is too long, and other factors intermediate training effectiveness.

Kirkpatrick's four-level evaluation is the most widely used evaluation model for training effectiveness. It was used to evaluate the training effectiveness of Taiwan's high-tech companies [22], the training effectiveness of higher education training programs [23,24], and the training effectiveness of programs for instructors at medical institutions [25]. The evaluation indicators at the result construct also include Kirkpatrick's four-level model. With that in consideration, this study uses Kirkpatrick's four-level model to evaluate training effectiveness.

\subsection{Service Quality}

Juran [26] defined "service" as "the job done for others"; the process of providing a service is intangible and cannot be predicted beforehand, much less can it be assessed with a specific measurement methodology. In 1988, Parasuraman, Zeithaml, and Berry developed a service quality scale called SERVQUAL, which is mainly used for measuring the service quality of four types of companies' customers [27]. These companies are banks, credit card companies, long-distance telephone companies, and equipment maintenance and repair companies. They established the conceptual model and ten constructs of service quality. Based on empirical studies in 1988 and some revisions, the 10 constructs for service quality were simplified into 5 constructs with 22 items. The five constructs are tangibles, reliability, responsiveness, assurance, and empathy [27]. Due to these revisions, SERVQUAL is more comprehensive in evaluating service quality. In addition, it has been used for studies on the relationship between various constructs of training effectiveness and service quality. Among these studies, it is mostly used in the study on the relationship between service quality and customer satisfaction. For example, SERVQUAL is used to evaluate the relationship of service quality of an English training institute and its learners' satisfaction [28]. In the higher education setting, existing studies focused only on the 
students to generate questionnaire items [29] and SERVQUAL is the most widely accepted scale [30]. Based on the above literature, SERVQUAL can not only be used to learn about the service quality of an organization but can also be used to evaluate the correlation between service quality and various constructs of training effectiveness.

According to the features of service quality, the degree of customer satisfaction about service quality could be a representation of their attitude. In other words, service quality is similar to an overall evaluation of the product [31]. Among the measurement models for attitudes developed by relevant scholars, Martin Fishbein's model is the most widely used [32]. Fishbein provided a reference for measuring the overall attitude by assuming that everything is composed of a group of properties that can be distinguished from each other. Therefore, by multiplying the extent of feeling and value attached to one certain property, we can get the attitude for the property and the overall attitude can be calculated by adding attitudes toall properties. Hence, this study will use SERVQUAL to evaluate service quality and to investigate the extent of feeling and value attached to each service construct by trainees.

\subsection{Individual Characteristics}

Personal characteristics, such as self-efficacy and learning motivation, are important factors that influence training effectiveness [3,6-9]. The word "motivation" was first discussed among psychologists. Different fields have different perspectives on the definition of motivation. Learning motivation refers to a student's motivation to achieve learning accomplishments. It is a psychological need that drives the individual to pursue success and is one of the important factors that influences learning accomplishment [33]. Trainees' learning motivation is a key factor that influences whether the training is going to be effective and successful [6]. When trainees can choose which program to take, they have a stronger motivation to learn, leading to a positive reaction toward the training, as well as better performance in exams [34]. Since learning motivation enables trainees to be psychologically prepared prior to training, it also improves their attention to and assimilation of new knowledge, showing a positive correlation with learning effectiveness. The measurement of learning motivation adopts the School Administrative Descriptive Survey (SADS) scale that mainly evaluates how subjects react to skill, point of control, work input, expectation, learning motivation, and exploratory behavior [35].

The idea of self-efficacy, derived from Bandura's sociological theory [36], is defined as the individual's belief in themselves achieving success. This belief is how the individual judges their ability to complete certain activities. Bandura [36] believed that self-efficacy is a main intermediate factor of individuals' behaviors. In other words, people with high selfefficacy are fully committed to their work and consequently achieve great accomplishments. Even when they fail, they attribute it to their lack of efforts. They confront the problem and remain positive despite external adversity. By contrast, people with low self-efficacy are unable to commit themselves to work; in the face of difficulty, they are prone to doubt their ability and give in, leading to psychological stress such as anxiety and fear, which affects their achievement. Multon, Brown, and Lent [37] believed that self-efficacy directly affects individual behavior, degree of effort, perseverance in the face of difficulty, and the ability to adjust behavior in response to different situations and work performance. Therefore, self-efficacy has an impact on individuals' work performances. In addition, such an effect is a critical one; that is to say, people with high self-efficacy will outperform people with low self-efficacy. The measurement for self-efficacy adopts the General Self-efficacy scale, which is widely used and developed for various cultures, including translation into Chinese [38].

\subsection{Relationships and Hypotheses}

Parasuraman, Zeithaml, and Berry [39] believed that the measurement of service quality and customer satisfaction is a comparison between expectation and performance; hence, the two cannot be completely differentiated. Good service quality can improve customer satisfaction and increase the repurchase rate; superior customer satisfaction can 
effectively improve service quality. The two are positively correlated [28,40], and service quality has proved to be the primary factor affecting customer satisfaction [41]. In the field of education, Camilleri [42] suggested that higher education institutions can use different performance indicators and metrics to evaluate their service quality. There also have been many studies on this correlation that verify the relationship between service quality and students' satisfaction $[43,44]$.

In the past, the research results of the effects of demographic variables on training effectiveness have been inconsistent. Tziner and Falbe [45]'s study on training-related variables, gender, and training outcome suggests that age has a significant impact on the reaction to the program. Past studies reveal that age is negatively correlated with training motivation, learning, and self-efficacy, because trainees that are relatively older perform worse on certain training results $[5,7,46]$. A foreign empirical study focusing on nine different organizations in the United States and Canada specifically investigated the degree of satisfaction of trainings for customer personnel and technicians. However, no difference was found in the degree of satisfaction of different ages, genders, and races toward the employment training [47].

Hypothesis 1 (H1). When trainees' background variables are controlled, the service quality and training effectiveness of vocational training organizations are positively correlated.

Moreover, personal characteristics that are predictive of training results include self-efficacy, objective orientation, learning motivation, and working environment features $[3,48]$. Baldwin and Ford's model analyzed factors influencing the transfer of learning, which is closely related to the two levels that are the most difficult to measure in training effectiveness evaluation, namely, behavior level and result level [20]. Among personal characteristics of trainees, the important characteristics, such as self-efficacy [49], learning methodology [50], attitude toward work [51,52], and motivation [4,53,54] have been suggested as the main factors that influence the transfer of training. Personal characteristics such as self-efficacy and learning motivation are important factors that influence training effectiveness [3,6-9] and the ability and motivation of trainees combined can determine training effectiveness [3-5]. When the trainees are able and motivated to learn, their training performance is enhanced.

Cheng and Ho [55] reviewed the studies in the past decade and concluded that training motivation affects the trainees' training performance and the transfer of results. Other studies on the positive correlation between training motivation and training effectiveness include a study on learning and satisfaction [46], perceived knowledge, and the transfer of skill [56]. Learning motivation affects whether the trainees are willing to apply the content acquired from the program to their work [20]. Learning motivation has a strong and positive impact on training effectiveness [35]. In addition, self-efficacy can enhance learning motivation, enabling trainees to acquire more knowledge, skills, and abilities [57]. Self-efficacy and the transfer of training results are positively correlated; when trainees have higher self-efficacy, they are more willing to apply the learned content from training to their work, hence facilitating the effective transfer of training [58].

Hypothesis 2 (H2). When the trainees' background variables are controlled, trainees' personal characteristics are significantly and positively correlated to training effectiveness.

\section{Methodology}

This study interviewed trainees that completed training sessions in beauty and hairdressing occupations for unemployed laborers provided by the Institute of Modeling and Artistry, R.O.C. The Institute of Modeling and Artistry, R.O.C. was established in October 2002 and became an aggregate corporation in 2010. It is a professional education and vocational-training organization composed of practical experts in the beauty and hairdressing industry. This association is a non-profit social organization that promotes the styling 
art of beauty salons and improves the styling standards of the industry. Its visions are to focus on the cultivation of talents for beauty salons and overall styling, to become an excellent talent training center trusted by the beauty and hairdressing industry, and to improve the effectiveness of education and training sustainably.

From 2010 to 2017, there were a total of 23 classes. Among these classes, six were taught in leasing venues outside the Institution and therefore have been removed from the study, while the rest of classes received trainings in the classrooms of the Institute of Modeling and Artistry, R.O.C. We interviewed a total of 17 classes and 479 trainees. The questionnaires were issued from December 2018 to January 2019. There were three stages of the issuance. In stage one, online questionnaires were issued in December 2018. In stage two, text messages were sent via cellphone to collect the questionnaires. In stage three, letters were sent out to collect the questionnaires. This study issued a total of 479 copies of the questionnaire and collected 216 copies, making the recovery rate $45 \%$. Of the 479 questionnaires, 216 copies remained valid after inspection; thus, the valid recovery rate is $100 \%$.

This study adopted a structured questionnaire. Based on related literature and the validity review of experts, four experts were invited—one assistant professor at a university, one executive director of a vocational training organization, one secretary general of a vocational training organization, and a senior instructor for vocational training - to conduct validity checks concerning the correctness, applicability, and coverage of the questionnaire. We revised the questionnaire and used it as the main research tool. The questionnaire is composed of four sections: the interviewee's basic information, training effectiveness, service quality, and personal characteristics.

Based on Kirkpatrick's definition of the four-level evaluation model and past studies on training effectiveness $[18,59]$, the inverse questions at the learning and behavior levels have been removed. There are three items at the reaction level, two items at the learning level, and three items at the behavior level. The training effectiveness questionnaire at the reaction, learning, and behavior levels adopt a Likert 5-point scale (from "strongly agree $=5$ " to "strongly disagree $=1$ ") to measure the interviewee's level of agreement with the items.

The result level, which had four items, started with a closed question, asking the interviewees to choose the time span between completion of their training and their first job acquired; employed interviewees are presented with another closed question asking them to choose whether the job's nature is related to the training, along with an open question asking them to describe the job's nature. Likewise, a closed question is presented to interviewees that asks them whether they are currently employed. If the answer is "yes", they will be presented with another closed question asking them to choose whether the job's nature is related to the training, along with an open question asking them to describe the job's nature.

The scoring for the four questions of the result level is as follows: for the question "After completing the training, how much time did it take for you to find the first job?", there is a 5point scale (from "within three months $=4$ ", "within six months $=3$ ", "within one year $=2$ ", "more than one year $=1$ " to "no job $=0$ "). For the other three questions "Following the previous question, is the job related to the training program?", "Do you have a job currently?" and "Following the previous question, is your current job related to the training program?" selecting "yes" or "no" gives one or zero points, respectively. Hence, the total score for the result level ranges from zero to seven.

According to Parasuraman, Zeithaml, and Berry [27], the definition of service quality, and the previous studies on service quality, we revised the questions to meet this study's purpose. The "Reliability" construct has four items, the "Responsiveness" construct has four items, the "Assurance" construct has three items, the "Empathy" construct has five items, and the "Tangibles" construct has four items. There are 20 items of service quality in total. The questionnaire adopted a Likert 5-point scale (from "strongly important $=5$ " to "strongly unimportant $=1$ ") to measure the respondents' level of importance for each 
service quality item. Similarly, a Likert 5-point scale (from "strongly satisfied $=5$ " to "strongly dissatisfied $=1$ ") was used to measure respondents' level of agreement regarding their feelings toward each service quality item.

The Martin Fishbein attitude model [32], was employed to calculate the respondents' overall attitude towards the service, which has a formula as shown in Formula 1. In the formula, $A_{0}$ represents the respondent's overall attitude toward the service quality; $n$ represents the total number of service quality items (20 items in total); $b_{i}$ represents the respondent's level of feeling toward item $i$ of service quality; and $e_{i}$ represents the level of importance that the respondent attaches to item $i$ of service quality. This study refers to Martin Fishbein's attitude model to evaluate the Institute of Modeling and Artistry, R.O.C., concerning its trainees' attitude toward service quality for the purpose of calculating the weights of various service quality items multiplied.

Formula (1):

$$
A_{0}=\sum_{i=1}^{n} b_{i} \times e_{i}
$$

$A_{0}$ : the respondent's overall attitude toward the service

$n$ : the total number of service items

$b_{i}$ : the respondent's level of feeling toward the service item $i$

$e_{i}$ : the level of importance that the respondent attaches to the service item $i$

According to Bandura's [36] definition of self-efficacy and the published studies on self-efficacy [38], the General Self-efficacy construct has 10 items. According to Noe and Schmitt's definition of learning motivation and literature about the SADS scale [35], the learning motivation construct includes 13 items. Only one item "Most things in life are more important than my job" was removed because all trainees were unemployed laborers, and that item is about the level of involvement with work and did not correspond to the background of unemployed trainees. The questionnaire (see Table A1) adopted a Likert 5-point scale (from "strongly agree $=5$ " to "strongly disagree $=1$ ") to measure the respondents' level of agreement regarding the item. The results of the reliability analyses were represented in Appendix A.

In order to test the two hypotheses of this study, multiple linear regressions were employed. The training organization's service quality and trainees' personal characteristics (self-efficacy and learning motivation) are the independent variables and the trainees' training effectiveness is the dependent variable of the regression models. Before the regression analyses, the analysis of variance (ANOVA) had been processed because the trainees' backgrounds, such as gender, age, nationality, education, and training hours might influence the trainees' training effectiveness and had to be controlled in the regression models.

\section{Analyses and Findings}

This study carried out a descriptive summary and analysis concerning five demographic variables and the results are shown in Table 1 . The five variables are the interviewees' gender, age, nationality, educational level, and training hours. The breakdown of the interviewed subjects are as follows: male (around 2\%); aged between 36 and 45 (around 37\%), aged under 35 years old (around 29\%), aged between 46 and 55 years old (around 23\%); non-Taiwanese nationality (around 35\%); high school (vocational) education (around $41 \%$ ), college and above (around 29\%), and junior college (around 21\%). The training hours for all trainees range between 300 to $360 \mathrm{~h}$. 
Table 1. Descriptive summary and analysis of interviewees' demographic variables $(n=216)$.

\begin{tabular}{|c|c|c|c|c|c|c|c|c|c|}
\hline & \multirow[b]{2}{*}{ Item } & \multirow{2}{*}{$\begin{array}{c}\text { Frequency } \\
(\%)\end{array}$} & \multirow{2}{*}{$\begin{array}{l}\text { Service } \\
\text { Quality }\end{array}$} & \multicolumn{2}{|c|}{ Personal Characteristics } & \multicolumn{4}{|c|}{ Training Effectiveness } \\
\hline & & & & $\begin{array}{c}\text { Self- } \\
\text { Efficacy }\end{array}$ & $\begin{array}{c}\text { Learning } \\
\text { Motivation }\end{array}$ & $\begin{array}{c}\text { Reaction } \\
\text { Level }\end{array}$ & $\begin{array}{c}\text { Learning } \\
\text { Level }\end{array}$ & $\begin{array}{c}\text { Behavior } \\
\text { Level }\end{array}$ & $\begin{array}{c}\text { Result } \\
\text { Level }\end{array}$ \\
\hline \multirow{2}{*}{ Gender } & Male & $4(1.85)$ & \multirow{2}{*}{-} & \multirow{2}{*}{-} & \multirow{2}{*}{-} & \multirow{2}{*}{-} & \multirow{2}{*}{-} & \multirow{2}{*}{-} & \multirow{2}{*}{-} \\
\hline & Female & $212(98.15)$ & & & & & & & \\
\hline \multirow{4}{*}{ Age } & Under 35 & $62(28.70)$ & \multirow{4}{*}{1.84} & \multirow{4}{*}{1.03} & \multirow{4}{*}{0.74} & \multirow{4}{*}{0.71} & \multirow{4}{*}{0.68} & \multirow{4}{*}{0.73} & \multirow{4}{*}{$8.52^{* * *}$} \\
\hline & $36-45$ & $80(37.04)$ & & & & & & & \\
\hline & $46-55$ & $50(23.15)$ & & & & & & & \\
\hline & 56 and above & $24(11.12)$ & & & & & & & \\
\hline \multirow[b]{2}{*}{ Nationality } & Taiwanese & $141(65.28)$ & \multirow{2}{*}{1.95} & \multirow{2}{*}{0.54} & \multirow{2}{*}{1.08} & \multirow{2}{*}{$3.98^{* *}$} & \multirow{2}{*}{1.40} & \multirow{2}{*}{0.03} & \multirow{2}{*}{2.04} \\
\hline & $\begin{array}{c}\text { Non- } \\
\text { Taiwanese }\end{array}$ & $75(34.72)$ & & & & & & & \\
\hline \multirow{4}{*}{ Education } & $\begin{array}{c}\text { Secondary } \\
\text { school or below }\end{array}$ & $19(8.80)$ & \multirow{4}{*}{0.21} & \multirow{4}{*}{1.65} & \multirow{4}{*}{1.88} & \multirow{4}{*}{0.37} & \multirow{4}{*}{0.83} & \multirow{4}{*}{0.22} & \\
\hline & $\begin{array}{l}\text { High school } \\
\text { (vocational) }\end{array}$ & $88(40.74)$ & & & & & & & 1.47 \\
\hline & Junior college & $46(21.30)$ & & & & & & & \\
\hline & $\begin{array}{l}\text { College and } \\
\text { above }\end{array}$ & 63(29.16) & & & & & & & \\
\hline Training & $251-300 \mathrm{~h}$ & $155(71.76)$ & 0.32 & 0.28 & 0.87 & 0.67 & 0.29 & 0.30 & 1.95 \\
\hline hours & $301-400 \mathrm{~h}$ & $61(28.24)$ & & & & & & & \\
\hline
\end{tabular}

Since the training program is for beauty and hairdressing occupations, the majority of the trainees are females. For the "Age" category, most of the trainees are aged between 36 and 45, followed by those aged between 26 and 35. The Workforce Development Agency has clearly stipulated regulations regarding the qualification of participating in training for unemployed laborers, which requests the trainees' age be between 15 and 65 . As a result, relatively fewer trainees are under 25 or above 45 . In the "Gender" category, female trainees (around 98\%) far outnumber male trainees (around $2 \%$ ). Therefore, "Gender" is not included in the inferential summary and analyses. Regarding the age distribution, people under the age of 35 account for around $29 \%$, people between the ages of 36 and 45 account for around $37 \%$, people between the ages of 46 and 55 account for around $23 \%$, and people aged 56 and above account for about $11 \%$. Regarding "Nationality", Taiwanese nationality (around 65\%) outweighs foreign nationality (around 35\%). Regarding the level of "Education", most people have a high school (vocational) education (around 41\%), followed by college and above (around 29\%), junior college (around 21\%) and secondary school or below (around 9\%). Regarding "Training hours", trainees who have gone through $251-300 \mathrm{~h}$ of training account for around $72 \%$, and those with $301-400 \mathrm{~h}$ of training account for around $28 \%$.

Table 1 also presents F-values and significances from ANOVA for the impacts of the five demographic variables on service quality, personal characteristics, and effectiveness of vocational training for unemployed laborers; only "Age" shows a significant difference on result level $(p<0.001)$ and "Nationality" has a significant difference on the reaction level $(p<0.05)$ of training effectiveness. Interviewees of different ages reach significant levels at the result level of training effectiveness $(p<0.001)$, indicating that interviewees with different ages have significant differences in terms of the result level of training effectiveness. Interviewees' ages do not have significant differences in service quality, self-efficacy, learning motivation of personal characteristics and the reaction, learning, and behavior levels of training effectiveness, indicating that interviewees of different ages do not have significant differences in terms of the above constructs. Interviewees with different nationalities have significant differences at the reaction level of training effectiveness 
$(p<0.05)$, indicating that non-Taiwanese interviewees have significant differences in terms of the reaction level of training effectiveness; there is no significant differences between Taiwanese and non-Taiwanese interviewees at the learning, behavior, and result levels of training effectiveness, as well as in self-efficacy, learning motivation, and service quality. Moreover, interviewees with different educational levels and training hours do not reach a significant level regarding service quality, personal characteristics, and training effectiveness, indicating that interviewees with different educational levels and training hours do not have significant differences in terms of the above constructs. Therefore, this study regards the two variables, age and nationality, which show significant differences in the analysis of difference, as control variables in the regression models.

Subsequently, this study adopts multiple linear regressions to forecast the organization's service quality and trainees' personal characteristics, concerning the influential coefficient and the model's explanatory power on the four levels of training effectiveness. The results are shown in Table 2. There is a total of eight multiple linear regressions shown in Table 2. The dependent variables are the four levels of trainees' training effectiveness; the organization's service quality and the trainees' personal characteristics are the independent variables. From the results of ANOVA, age would be set as a controlled variable of regression models for the result level of trainees' training effectiveness. Nationality is set as a controlled variable of the regression models for the reaction level of trainees' training effectiveness.

Table 2. Regression analysis of training effectiveness $(n=216)$.

\begin{tabular}{|c|c|c|c|c|c|c|c|c|}
\hline \multirow{2}{*}{ Variables } & \multicolumn{2}{|c|}{ Reaction Level } & \multicolumn{2}{|c|}{ Learning Level } & \multicolumn{2}{|c|}{ Behavior Level } & \multicolumn{2}{|c|}{ Result Level } \\
\hline & $\beta(\mathrm{SE})$ & $\beta(\mathrm{SE})$ & $\beta(\mathrm{SE})$ & $\beta(\mathrm{SE})$ & $\beta(\mathrm{SE})$ & $\beta(\mathrm{SE})$ & $\beta(\mathrm{SE})$ & $\beta(\mathrm{SE})$ \\
\hline $\begin{array}{l}\text { Service } \\
\text { Quality }\end{array}$ & $0.07(0.01)^{* * *}$ & & $0.06(0.01)^{* * *}$ & & $0.02(0.01)$ & & $-0.01(0.05)$ & \\
\hline Reliability & & $0.05(0.02)^{* *}$ & & $0.09(0.02)^{* * *}$ & & $0.08(0.04)$ & & $0.35(0.14)^{* *}$ \\
\hline Responsiveness & & $-0.02(0.02)$ & & $-0.03(0.02)$ & & $-0.04(0.04)$ & & $-0.16(0.15)$ \\
\hline Assurance & & $0.00(0.02)$ & & $-0.02(0.03)$ & & $-0.06(0.04)$ & & $-0.15(0.16)$ \\
\hline Empathy & & $0.00(0.02)$ & & $-0.02(0.02)$ & & $0.00(0.04)$ & & $0.04(0.13)$ \\
\hline Tangibles & & $0.02(0.02)$ & & $0.03(0.02)$ & & $0.05(0.04)$ & & $-0.08(0.13)$ \\
\hline $\begin{array}{c}\text { Personal } \\
\text { Characteris- } \\
\text { tics }\end{array}$ & $0.15(0.07)^{* *}$ & & $0.30(0.07)^{* * *}$ & & $0.77(0.12)^{* * *}$ & & $1.28(0.41)^{* *}$ & \\
\hline Self-efficacy & & $-0.09(0.07)$ & & $0.09(0.08)$ & & $0.30(0.13)^{* *}$ & & $0.16(0.46)$ \\
\hline $\begin{array}{l}\text { Learning } \\
\text { motivation }\end{array}$ & & $0.28(0.09)^{* *}$ & & $0.22(0.09)^{* *}$ & & $0.45(0.16) * *$ & & $1.19(0.56)^{* *}$ \\
\hline \multicolumn{9}{|c|}{ Age (Reference Group: Under 35) } \\
\hline $36-45$ & - & - & - & - & - & - & $0.22(0.40)$ & $0.31(0.40)$ \\
\hline $46-55$ & - & - & - & - & - & - & $\underset{* *}{-0.95(0.46)}$ & $-0.87(0.47)$ \\
\hline 56 and above & - & - & - & - & - & - & $\underset{* * *}{-2.21(0.58)}$ & $-\underset{* * *}{-2.32(0.58)}$ \\
\hline \multicolumn{9}{|c|}{ Nationality (Reference Group: Taiwanese) } \\
\hline $\begin{array}{c}\text { Non- } \\
\text { Taiwanese }\end{array}$ & $0.08(0.06)$ & $0.09(0.06)$ & - & - & - & - & - & - \\
\hline Adjusted $\mathrm{R}^{2}$ & 0.52 & 0.53 & 0.53 & 0.56 & 0.35 & 0.36 & 0.16 & 0.18 \\
\hline
\end{tabular}

Note 1: Age is controlled at the result level; nationality is controlled at the reaction level. Note 2: $\beta=$ non-standardized coefficient; $\mathrm{SE}=$ standard error; ${ }^{* * *} p<0.001,{ }^{* *} p<0.05$

In general, service quality and personal characteristics have over $50 \%$ explanatory power at the reaction level and learning level of training effectiveness $\left(R^{2}>50 \%\right)$ and over $35 \%$ explanatory power at the behavior level of training effectiveness $\left(R^{2}>35 \%\right)$. Training organizations' service quality has significant and positive impacts on the reaction level and learning level of trainees' training effectiveness, exerting no significant impact on the behavior level and result level. The reaction level represents trainees' overall level of satisfaction with the training program; the learning level denotes trainees' learning 
performance; these results are consistent with that of previous studies [43,44]. An important factor of service quality, that is, the staff of organization (teachers and employers), would affect the achievement performance of students [29]. This study further discovered that the "Reliability" of training organizations' service quality mainly influences the reaction level, learning level, and result level.

Trainees' personal characteristics have significant and positive impacts on all four levels of training effectiveness. In particular, "Learning motivation" has positive impacts on all four levels of training effectiveness; these results are consistent with that of previous studies. Some papers suggested that learning motivation affects the trainees' transfer of results from training effectiveness; other studies on the positive correlation between learning motivation and training effectiveness include learning and satisfaction [46], perceived knowledge, and the transfer of skill [56]. With regards to "Self-efficacy", these research results reveal a positive impact at the behavior level of training effectiveness, consistent with past literature as well, suggesting that there is a positive correlation between "Selfefficacy" and the transfer of training results. When trainees have higher self-efficacy, they are more willing to apply what they learn from the training to their work, so as to facilitate the transfer of training [58].

Regarding the two control variables of trainees' demographic variables ("Age" and "Nationality") in Table 2, the results show that the older the trainees performed significantly worse on training effectiveness, and it is particularly significant for trainees over the age of 46. This result is consistent with the results of other published studies $[5,7,46]$.

\section{Discussions and Suggestions}

This study draws on the vocational training of beauty and hairdressing occupations for unemployed laborers and interviews trainees who completed vocational training on beauty and hairdressing occupations for unemployed laborers provided by the Institute of Modeling and Artistry, R.O.C. from 2010 to 2017. The aim of this paper is to discuss the influences of vocational training organizations' service quality and trainees' personal characteristics according to the four effectiveness levels of vocational training for unemployed laborers. Training organizations' service quality and trainees' personal characteristics significantly and positively affect trainees' training effectiveness when the trainees' background variables ("Age" and "Nationality") are controlled. This concludes that both of the hypotheses (H1 and H2) are valid.

With more in-depth discussions, it was found that when the service quality of the training organization is better, particularly the "Reliability" dimension, the trainees' performance at the reaction level and learning level of training effectiveness is better. It indicates that factors such as the organization's commitment at the right time, precise and impeccable services, and helping as much as possible when trainees have difficulties are most valued by trainees. To achieve the sustainability of vocational trainings, training organizations need to emphasize the quality of services provided by the organization's staff (teachers and employers). This result might provide feedback to training organizations for a thorough retrospective and serve as a reference for the future development of their systems.

Moreover, the research results also show that the stronger the "Learning motivation" of trainees' personal characteristics are, the better they perform at the behavior level of training effectiveness; the stronger the "Self-efficacy" of trainees' personal characteristics are, the better they perform at all four levels of training effectiveness. As a result, trainees' learning motivations are a key point that affects training effectiveness at all levels, so it is important for training organizations to provide incentives to stimulate trainees' learning motivations. Likewise, when the trainee believes in their ability to complete the training, they are better at applying the knowledge and skills acquired through training in their work. These results might be used to incentivize training organizations to include learning motivation and self-efficacy as important reference factors when they develop the selecting mechanism for trainees. In selecting applicants, training organizations might consider filtering out applicants with relatively low learning motivation, so as not to waste the 
resources and quota of the organization, enabling the vocational training to play its role against the backdrop of industrial competition and maximizing the benefit of training.

On the perspective of trainees' age, the research results displayed that the older the trainees are, the worse they perform at the result level of training effectiveness. Therefore, it should behoove training organizations, when working on the selecting mechanism for trainees, to set their primary prospect as relatively younger people. Furthermore, organizations could strengthen training for people over the age of 46 to improve the result level of training effectiveness. On the perspective of "Nationality", the ANOVA test showed that effectiveness at the reaction level has significant differences, while "Nationality" did not reveal a significant relationship with the reaction level of training effectiveness in the regression models. Around $35 \%$ of the interviewees were non-Taiwanese in nationality. With the trend of gradually increasing new residents, the number of new residents enrolling in training is expected to continuously increase as well. Although the results show that nationality has no significant impact on the reaction level of training effectiveness, "Nationality" is a factor worthy of in-depth discussion in the future; for example, cultural differences and language communication might affect training effectiveness. Besides, since this study did not consider institutional or national effects, the results might not be applied to other types of training. Future studies might expand the research to include other types of training organizations to carry out comparisons.

From an academic standpoint, this study provided significant evidence of the influences of service quality and personal characteristics on the training effectiveness of the vocational training on beauty and hairdressing occupations for unemployed laborers, and it also successfully fills the gap in the literature. From a practical standpoint, this paper provides a reference to training organizations and the Workforce Development Agency of the Ministry of Labor, for the purpose of improving and monitoring the service quality of training organizations, positively influencing training effectiveness, and achieving sustainability for vocational educations.

Author Contributions: Conceptualization, Formal analysis, Funding acquisition, Investigation, Methodology, Project administration, Supervision, Validation, Visualization, Writing — original draft, W.H.; Data curation, Resources, Software, Writing—review \& editing, P.-W.C. All authors have read and agreed to the published version of the manuscript.

Funding: This research was funded by National Taipei University of Nursing \& Health Sciences, under grant number 107D041 to Wei Hsu.

Institutional Review Board Statement: All participants of this study are adult trainees (20-65 yearold) of the case institution and not patients. The data collection was processed and completed by internal personnel of the case institution for the intent and purposes of improving services. All subjects in this study were informed of the testing procedures and voluntarily participated in the data collection. The participants were assured that their responses would be confidential and anonymous. All data are not identifiable. Ethical review and approval were waived for this study, due to the type of the experiment, which includes only use of standardized psychological questionnaires which are used for training evaluations and had been conducted and employed in numerous published studies. As the study does not include any attributes of medical experiments, the study was conducted according to the guidelines of the Declaration of Helsinki and Ethical Committee protocol was not required.

Informed Consent Statement: Not applicable.

Data Availability Statement: Not applicable.

Acknowledgments: The authors would like to thank the editorial team of Sustainability and anonymous reviewers who provided valuable comments and suggestions for improving the quality of this paper.

Conflicts of Interest: The authors declare no conflict of interest. 


\section{Appendix A. Reliability Analyses of the Instrument}

The questionnaire items and reliability analyses of this study were shown in Table A1. According to the reliability analysis of the data collected by the instrument of this study, the training effectiveness scales at the reaction, learning, and behavior levels show a Cronbach's $\alpha$ of 0.86 . The overall reliability analysis toward service quality has a Cronbach's $\alpha$ of 0.99 . The personal characteristic construct from the General Self-efficacy scale and SADS scale has the Cronbach's $\alpha$ of 0.98 . As a result, the instrument of this study has consistency and high reliability. It might be due to maturity of the theories and models, so the questionnaires of training effectiveness, service quality, and personal characteristics all have consistency and high reliability.

Table A1. The Reliability Analyses of Questionnaires.

\begin{tabular}{|c|c|}
\hline \multicolumn{2}{|c|}{ Training Effectiveness (Cronbach's $\alpha=0.86$ ) } \\
\hline Reaction Level & $\begin{array}{l}\text { 1. I was very satisfied with the instruction in the class. } \\
\text { 2. I was very satisfied with the course content. } \\
\text { 3. Overall, I was very satisfied with the class. }\end{array}$ \\
\hline Learning Level & $\begin{array}{l}\text { 1. I learned a lot in this class. } \\
\text { 2. I remember almost everything covered in the class. }\end{array}$ \\
\hline Behavior Level & $\begin{array}{l}\text { 1. I have applied the things covered into my work. } \\
\text { 2. I use almost everything that was covered in my work. } \\
\text { 3. I use the thing covered in this class almost every day. }\end{array}$ \\
\hline \multicolumn{2}{|c|}{ Service Quality (Cronbach's $\alpha=0.99$ ) } \\
\hline Reliability & $\begin{array}{l}\text { 1. When the training organization promises to do something by a certain time, it } \\
\text { dose so. } \\
\text { 2. The training organization performs the service right the first time. } \\
\text { 3. The training organization provides its service at the time it promises to do so. } \\
\text { 4. The training organization insists on error-free records. }\end{array}$ \\
\hline Responsive-ness & $\begin{array}{l}\text { 1. The training organization keeps trainees informed about when service will } \\
\text { be performed. } \\
\text { 2. Employees in the training organization give you prompt service. } \\
\text { 3. Employees in the training organization are always willing to help you. } \\
\text { 4. Employees in the training organization are never too busy to respond to } \\
\text { your request. }\end{array}$ \\
\hline Assurance & $\begin{array}{l}\text { 1. The behavior of employees in the training organization instills confidence } \\
\text { in you. } \\
\text { 2. Employees in the training organization are consistently courteous with you. } \\
\text { 3. Employees in the training organization have the knowledge to answer } \\
\text { your questions. }\end{array}$ \\
\hline Empathy & $\begin{array}{l}\text { 1. The training organization gives you individual attention. } \\
\text { 2. The training organization has employees who give you personal attention. } \\
\text { 3. The training organization has your best interests at heart. } \\
\text { 4. Employees of the training organization understand your specific needs. } \\
\text { 5. The training organization has operating hours that are convenient to all } \\
\text { its trainees. }\end{array}$ \\
\hline Tangibles & $\begin{array}{l}\text { 1. The training organization has modern-looking equipment. } \\
\text { 2. The training organization's physical facilities are visually appealing. } \\
\text { 3. The training organization's employees appear neat. } \\
\text { 4. Materials associated with the service. }\end{array}$ \\
\hline
\end{tabular}


Table A1. Cont.

\section{Personal Characteristic (Cronbach's $\alpha=0.98$ )}

Self-efficacy
1. I can always manage to solve difficult problems if I try hard enough.

2. If someone opposes me. I can find means and ways to get what I want

3. It is easy for me to stick to my aims and accomplish my goals.

4. I am confident that I could deal efficiently with unexpected events.

5. Thanks to my resourcefulness, I know how to handle unforeseen situations.

6. I can solve most problems if I invest the necessary effort.

7. I can remain calm when facing difficulties because I can rely on my coping abilities.

8. When I am confronted with a problem, I can usually find several solutions.

9. If I am in a bind, 1 can usually think of something to do.

10. No matter what comes my way, I'm usually able to handle it.

Learning Motivation

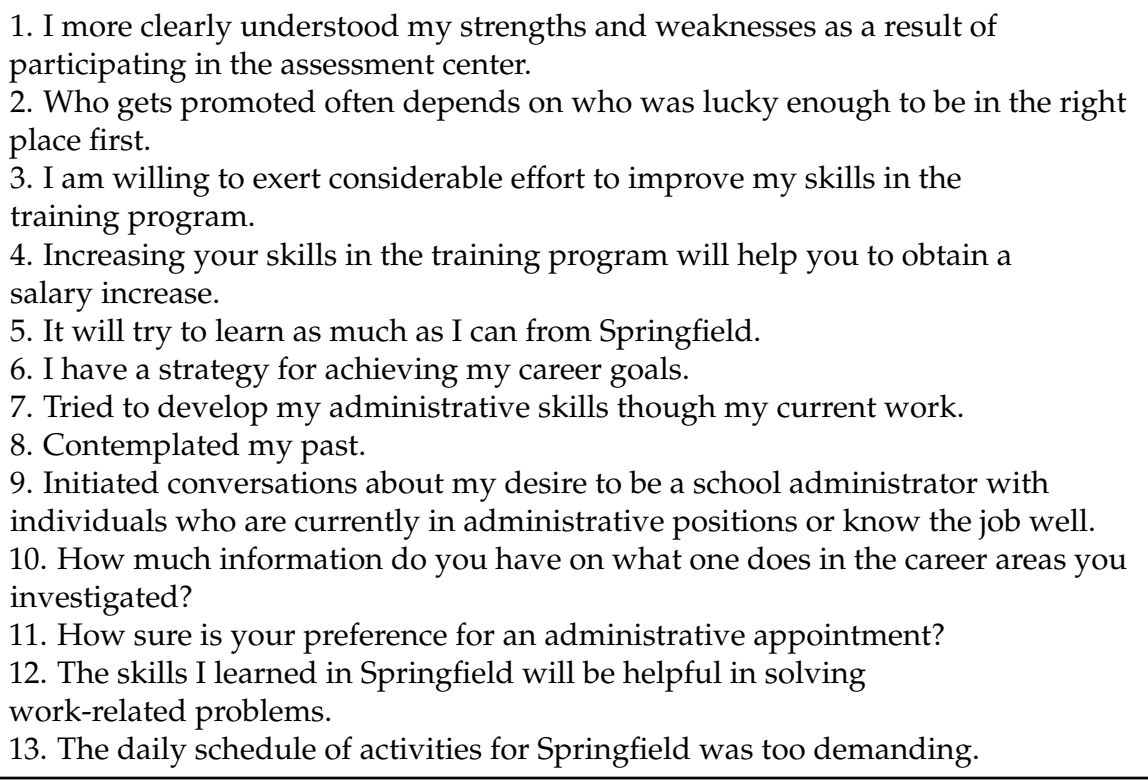

\section{References}

1. Ashton, D.; Green, F.; Sung, J.; James, D. The Evolution of Education and Training Strategies in Singapore, Taiwan and S. Korea: A development model of skill formation. J. Educ. Work 2002, 15, 5-30. [CrossRef]

2. Tai, C.-F.; Chen, R.-J.; Lai, J.-L. How technological and vocational education can prosper in the 21st century. IEEE Circuits Devices Mag. 2003, 19, 15-51. [CrossRef]

3. Mathieu, J.E.; Tannenbaum, S.I.; Salas, E. Influences of individual and situational characteristics on measures of training effectiveness. Acad. Manag. J. 1992, 35, 828-847.

4. Noe, R.A.; Wilk, S.L. Investigation of the factors that influence employees' participation in development activities. J. Appl. Psychol. 1993, 78, 291-302. [CrossRef]

5. Colquitt, J.A.; Lepine, J.A.; Noe, R.A. Toward an integrative theory of training motivation: A meta-analytic path analysis of 20 years of research. J. Appl. Psychol. 2000, 85, 678-707. [CrossRef] [PubMed]

6. Noe, R.A. Trainees attributes and attitudes: Neglected influences on training effectiveness. Acad. Manag. Rev. 1986, 11, 736-749. [CrossRef]

7. Gist, M.E.; Schwoerer, C.; Rosen, B. Effect of alternative training methods on self-efficacy and performance in computer software training. J. Appl. Psychol. 1989, 74, 884-891. [CrossRef]

8. Tai, W. Effects of training framing, general self-efficacy and training motivation on trainees' training effectiveness. Pers. Rev. 2006, 35, 51-65. [CrossRef]

9. Homklin, T.; Takahashi, Y.; Techakanont, K. Effects of Individual and Work Environment Characteristics on Training Effectiveness: Evidence from Skill Certification System for Automotive Industry in Thailand. Int. Bus. Res. 2013, 6, 1-16. [CrossRef]

10. Ibrahim, M.Z.; Ab Rahman, M.N.; Yasin, R.M. Assessing students perceptions of service quality in technical edu-cational and vocational training (TEVT) institution in Malaysia. Procedia-Soc. Behav. Sci. 2012, 56, 272-283. [CrossRef] 
11. Kuo, Y.-K.; Ye, K.-D. The causal relationship between service quality, corporate image and adults' learning satisfaction and loyalty: A study of professional training programmes in a Taiwanese vocational institute. Total. Qual. Manag. Bus. Excel. 2009, 20, 749-762. [CrossRef]

12. Miljus, R.C.; Campbell, J.P.; Dunnette, M.D.; Lawler, E.E.; Weick, K.E. Managerial Behavior, Performance, and Effectiveness. ILR Rev. 1971, 24, 487. [CrossRef]

13. Kucherov, D.; Manokhina, D. Evaluation of training programs in Russian manufacturing companies. Eur. J. Train. Dev. 2017, 41, 119-143. [CrossRef]

14. Bushnell, D.S. Input, process, output: A model for evaluating training. Train. Dev. J. 1990, 44, 41-43.

15. Arthur, W., Jr.; Bennett, W., Jr.; Edens, P.S.; Bell, S.T. Effectiveness of training in organizations: A meta-analysis of design and evaluation features. J. Appl. Psychol. 2003, 88, 234-245. [CrossRef] [PubMed]

16. Noe, R. Invited reaction: Development of a generalized learning transfer system inventory. Hum. Resour. Dev. Q. 2000, 11, 361-365. [CrossRef]

17. Pineda, P. Evaluation of training in organisations: A proposal for an integrated model. J. Eur. Ind. Train. 2010, 34, 673-693. [CrossRef]

18. Kirkpatrick, D.L. Evaluating Training Programs: The Four Levels; Berrett-Koehler: San Francisco, CA, USA, 1994.

19. Kirkpatrick, D.L.; Kirkpatrick, J.D. Evaluating Training Programs: The Four Levels, 3rd ed.; Ber-rett-Koehler: San Francisco, CA, USA, 2006.

20. Baldwin, T.T.; Ford, J.K. Transfer of training: A review and directions for future research. Pers. Psychol. 1988, 41, 63-105. [CrossRef]

21. Gully, S.M.; Chen, G. Individual differences, attribute-treatment interactions, and training outcomes. In Learning, Training, and Development in Organizations; Kozlowski, S.W.J., Salas, E., Eds.; Routledge: New York, NY, USA, 2010; pp. 3-64.

22. Lien, B.Y.H.; Hung, R.Y.Y.; McLean, G.N. Training evaluation based on cases of Taiwanese benchmarked high-tech companies. Int. J. Train. Dev. 2007, 11, 35-48. [CrossRef]

23. Farjad, S. The Evaluation Effectiveness of Training Courses in University by Kirkpatrick Model (Case Study: Islamshahr University). Procedia-Soc. Behav. Sci. 2012, 46, 2837-2841. [CrossRef]

24. Mollahoseini, A.; Farjad, S. Assessment Effectiveness on the Job Training in Higher Education (Case Study: Takestan University). Procedia-Soc. Behav. Sci. 2012, 47, 1310-1314. [CrossRef]

25. Masood, R.Q.; Usmani MA, W. Evaluation of medical teacher's training program through Kirkpatrick's model. Khyber Med Univ. J. 2015, 7, 76-80.

26. Juran, J.M. The quality trilogy. Qual. Prog. 1986, 19, 19-24.

27. Parasuraman, A.; Zeithaml, V.A.; Berry, L.L. Servqual: A multiple-item scale for measuring consumer perceptions of service quality. J. Retail. 1988, 64, 12-40.

28. Huong, V.T.; Casadesús, M.; Marimon, F. Assessing learner satisfaction by simultaneously measuring learner attitude, motivation, loyalty and service quality in English academies. Innov. Educ. Teach. Int. 2015, 54, 301-312. [CrossRef]

29. Latif, K.F.; Latif, I.; Farooq Sahibzada, U.; Ullah, M. In search of quality: Measuring higher education service qual-ity (HiEduQual). Total. Qual. Manag. Bus. Excell. 2019, 30, 768-791. [CrossRef]

30. Gupta, P.; Kaushik, N. Dimensions of service quality in higher education-critical review (students' perspective). Int. J. Educ. Manag. 2018, 32, 580-605. [CrossRef]

31. Holbrook, M.B.; Lehmann, D.R. Allocating Discretionary Time: Complementarity among Activities. J. Consum. Res. 1981, 7, 395-406. [CrossRef]

32. Robertson, T.; Zielinski, J.; Ward, S. Consumer Behavior; Scott, Foresman: Glenview, IL, USA, 1984.

33. Stipek, D.; Feiler, R.; Daniels, D.; Milburn, S. Effects of different instructional approaches on young children's achievement and motivation. Child Dev. 1995, 66, 209-223. [CrossRef]

34. Hicks, W.D.; Klimoski, R.J. Entry into training programs and its effects on training outcomes: A field experiment. Acad. Manag. J. 1987, 30, 542-552. [CrossRef]

35. Noe, R.A.; Schmitt, N. The influence of trainee attitudes on training effectiveness: Test of a model. Pers. Psychol. 1986, 39, 497-523. [CrossRef]

36. Bandura, A. Social Foundations of Thought and Action: A Social Cognitive Theory; Prentice-Hall: Englewood Cliffs, NJ, USA, 1986.

37. Multon, K.D.; Brown, S.D.; Lent, R.W. Relation of self-efficacy beliefs to academic outcomes: A meta-analytic in-vestigation. J. Couns. Psychol. 1991, 38, 30-38. [CrossRef]

38. Schwarzer, R.; Bäßler, J.; Kwiatek, P.; Schröder, K.; Zhang, J.X. The assessment of optimistic self-beliefs: Comparison of the German, Spanish, and Chinese versions of the general self-efficacy scale. Appl. Psychol. 1997, 46, 69-88. [CrossRef]

39. Parasuraman, A.; Zeithaml, V.A.; Berry, L.L. A conceptual model of service quality and its implications for future research. J. Mark. 1985, 49, 41-50. [CrossRef]

40. Woodside, A.G.; Frey, L.L.; Daly, R.T. Linking service quality, customer satisfaction, and behavioral intention. J. Health Mark. 1989, 9, 5-17.

41. Szymanski, D.M.; Henard, D.H. Customer satisfaction: A meta-analysis of the empirical evidence. J. Acad. Mark. Sci. 2001, 29, 16-35. [CrossRef] 
42. Camilleri, M.A. Evaluating service quality and performance of higher education institutions: A systematic review and a post-COVID-19 outlook. Int. J. Qual. Serv. Sci. 2021, 13, 268-281. [CrossRef]

43. Duque, L.C.; Lado, N. Cross-cultural comparisons of consumer satisfaction ratings: A perspective from Albert Hirschman's theory. Int. Mark. Rev. 2010, 27, 676-693. [CrossRef]

44. Gruber, T.; Fub, S.; Voss, R.; Glaser-Zikuda, M. Examining student satisfaction with higher education services using a new measurement tool. Int. J. Public Sect. Manag. 2010, 23, 105-123. [CrossRef]

45. Tziner, A.; Falbe, C.M. Training-Related Variables, Gender and Training Outcomes: A Field Investigation. Int. J. Psychol. 1993, 28, 203-221. [CrossRef]

46. Guerrero, S.; Sire, B. Motivation to train from the workers' perspective: Example of French companies. Int. J. Hum. Resour. Manag. 2001, 12, 988-1004. [CrossRef]

47. Schmidt, S.W. Employee demographics and job training satisfaction: The relationship between dimensions of diversity and satisfaction with job training. Hum. Resour. Dev. Int. 2009, 12, 297-312. [CrossRef]

48. Towler, A.J.; Dipboye, R.L. Effects of trainer expressiveness, organization, and trainee goal orientation on training outcomes. $J$. Appl. Psychol. 2001, 86, 664-673. [CrossRef] [PubMed]

49. Tracey, J.B.; Hinkin, T.R.; Tannenbaum, S.; Mathieu, J.E. The influence of individual characteristics and the work environment on varying levels of training outcomes. Hum. Resour. Dev. Q. 2001, 12, 5-23. [CrossRef]

50. Murphy, S.M.; Tyler, S. The Relationship Between Learning Approaches to Part-Time Study of Management Courses and Transfer of Learning to the Workplace. Educ. Psychol. 2005, 25, 455-469. [CrossRef]

51. Kontoghiorghes, C. Reconceptualizing the learning transfer conceptual framework: Empirical validation of a new systemic model. Int. J. Train. Dev. 2004, 8, 210-221. [CrossRef]

52. Velada, R.; Caetano, A.; Michel, J.W.; Lyons, B.D.; Kavanagh, M.J. The effects of training design, individual characteristics and work environment on transfer of training. Int. J. Train. Dev. 2007, 11, 282-294. [CrossRef]

53. Naquin, S.; Holton, E. Motivation to improve work through learning in human resource development. Hum. Resour. Dev. Int. 2003, 6, 355-370. [CrossRef]

54. Holton, E.F., III. Holton's evaluation model: New evidence and construct elaborations. Adv. Dev. Hum. Resour. 2005, 7, 37-54. [CrossRef]

55. Cheng, E.W.; Ho, D.C. A review of transfer of training studies in the past decade. Pers. Rev. 2001, 30, 102-118. [CrossRef]

56. Cheng, E.W. Test of the MBA knowledge and skills transfer. Int. J. Hum. Resour. Manag. 2000, 11, 837-852. [CrossRef]

57. Tziner, A.; Fisher, M.; Senior, T.; Weisberg, J. Effects of Trainee Characteristics on Training Effectiveness. Int. J. Sel. Assess. 2007, 15, 167-174. [CrossRef]

58. Bhatti, M.A.; Kaur, S. The role of individual and training design factors on training transfer. J. Eur. Ind. Train. 2010, 34, 656-672. [CrossRef]

59. Carlfjord, S.; Roback, K.; Nilsen, P. Five years' experience of an annual course on implementation science: An evaluation among course participants. Implement. Sci. 2017, 12, 101-108. [CrossRef] [PubMed] 